\title{
PEMANFAATAN POWERPOINT TERINTEGRASI DENGAN I-SPRING PRESENTER SEBAGAI MEDIA PEMBELAJARAN ICT
}

\author{
Khusnul Khotimah ${ }^{1}$ \\ ${ }^{1}$ STKIP Muhammadiyah Kotabumi \\ Email : $\underline{\text { ima.ukhti@gmail.com }}$
}

\begin{abstract}
The use of technology in the field of education has become a fundamental necessity. One such technological involvement can be seen in the learning activities in the classroom. Many applications/software that can be used as a learning tool, two of which are Microsoft Powerpoint and ispring presenter. Microsoft Powerpoint Application integrated ispring presenter can be used as an alternative in the creation of ICT learning media. Learning Media is produced by observing the right design supported by various animations, audio/video making the learning process more interesting, the presentation of the material becomes more effective so that it will be easier To be understood by learners.
\end{abstract}

\section{Keywords : Media pembelajaran, powerpoint, I-Spring Presenter, ICT}

\section{A. Pedahuluan}

Teknologi yang berkembang saat ini memberikan dampak perubahan yang besar dalam kehidupan manusia di berbagai bidang. Salah satu bidang yang juga terkena dampak perkembangan teknologi saat ini yaitu bidang pendidikan. Dalam bidang pendidikan implementasi pembelajaran dalam proses belajar mengajar saat ini tidak dapat dipungkiri adanya keterlibatan teknologi. Dengan berkembangnya teknologi, banyak hal yang dapat dilakukan salah satunya memanfaatkan teknologi dalam pembuatan media pembelajaran.

Menurut Asyar (2012:8) media pembelajaran dapat dipahami sebagai segala sesuatu yang dapat menyampaikan atau menyalurkan pesan dari sumber secara terencana, sehingga terjadi lingkungan belajar yang kondusif dimana penerimanya dapat melakukan proses belajar secara efisien dan efektif. Arsyad (2011:15) mengemukakan fungsi utama media pembelajaran adalah sebagai alat bantu mengajar yang turut mempengaruhi iklim, kondisi, dan lingkungan belajar. Menurut Fathurrohman dkk (2014:67) terdapat tiga bentuk media pembelajaran, meliputi: 1) media audio, merupakan media yang hanya mengandalkan kemampuan dari suara saja seperti radio, cassete recorder, dan piringan hitam; 2) media visual, merupakan media yang mengandalkan pada tampilan secara visual melalui indera penglihatan seperti gambar, film tanpa suara; c) media audio visual, merupakanmedia yang memiliki unsur suara dan gambar seperti televisi dan CD (Compact Disk) pembelajaran. Menurut 
Sehingga dari beberapa pendapat tersebut dapat disimpulkan bahwa media pembelajaran merupakan alat bantu yang dapat digunakan secara efisien dan efektif untuk menyampaikan pesan/materi bisa berbentuk media audio, visual, dan audio visual yang turut mempengaruhi iklim, kondisi dan lingkungan belajar.

Media pembelajaran dengan berbagai bentuk tampilan yang di rancang dengan tepat dapat memberikan nilai tambah dalam proses kegiatan belajar mengajar. Media pembelajaran yang dibuat haruslah memberikan kontribusi dalam memperbaiki mutu dan kualitas pembelajaran. Terdapat beberapa aplikasi/software yang dapat digunakan dalam pembuatan media pembelajaran, dua diantaranya adalah microsoft power point dan I-spring presenter. Kedua applikasi ini dapat diintegrasikan untuk merancang media pembelajaran berbentuk persentasi.

\section{B. Microsoft Powerpoint}

Menurut Rusman dkk (2012:301) microsoft powerpoint merupakan salah satu aplikasi/software yang didesain untuk menampilkan aplikasi multimedia dengan menarik, kemudahan dalam penggunaan dan relatif murah. Widada (2010:9) menjelaskan bahwa program powerpoint adalah salah satu software yang dirancang khusus untuk menampilkan program multimedia menarik, mudah dalam pembuatan, mudah dalam penggunaan dan relatif murah, karena tidak membutuhkan bahan baku selain alat untuk menyimpan data. powerpoint merupakan program pengolah presentasi yang mudah digunakan dan memuat berbagai fasilitas yang siap pakai untuk memperindah tampilan sebuah presentasi, seperti background, layout slide, efek teks, animasi objek, serta menambah audio atau video. Microsoft powerpoint ini salah satu bagian dari paket aplikasi/software microsoft office dan merupakan produk unggulan Microsoft yang paling banyak digunakan pada saat ini. Berikut beberapa gambar tampilan menu pada aplikasi microsoft powerpoint.

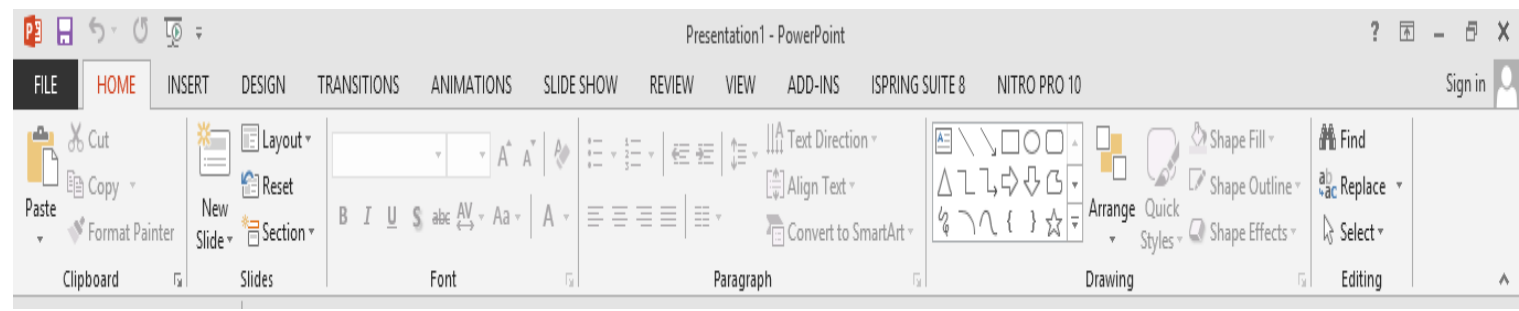

Gambar 1. Tampilan menu home microsoft powerpoint 


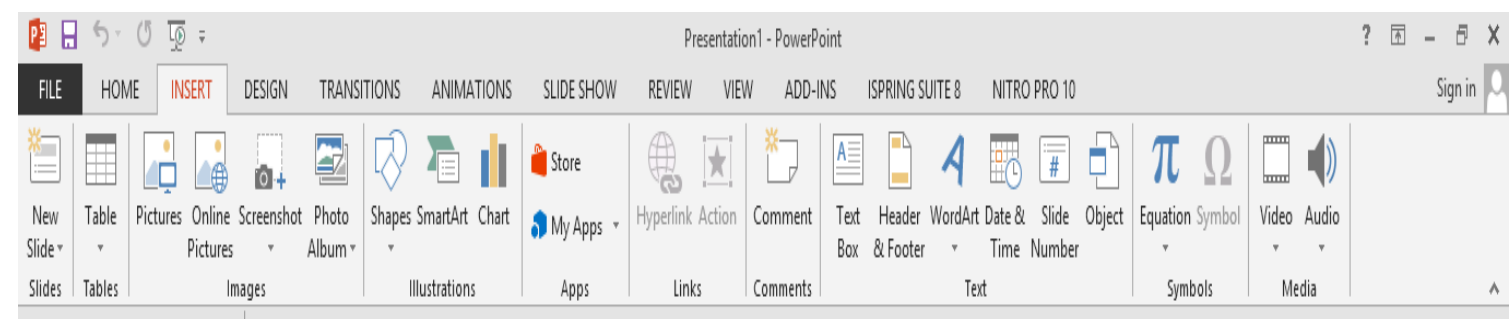

Gambar 2. Tampilan menu insert microsoft powerpoint

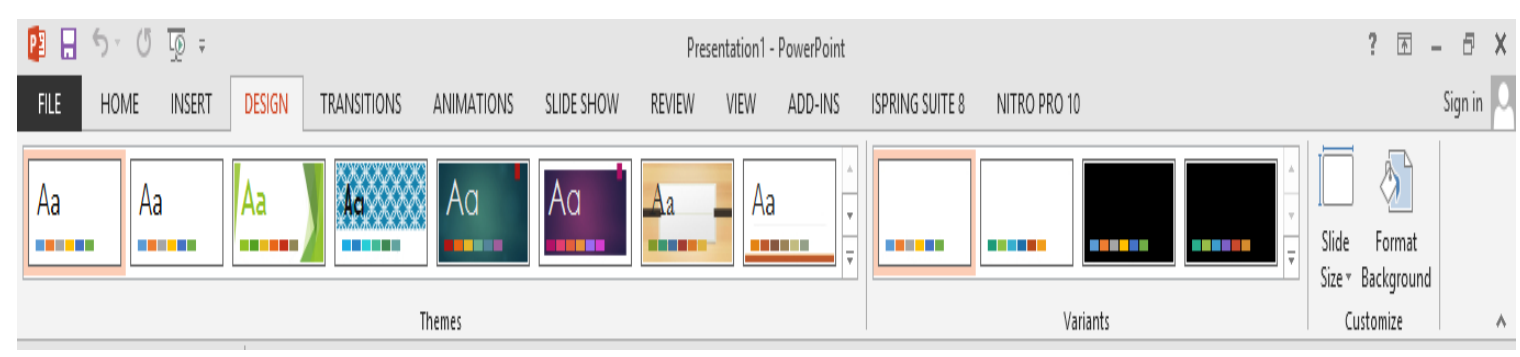

Gambar 3. Tampilan menu design microsoft powerpoint

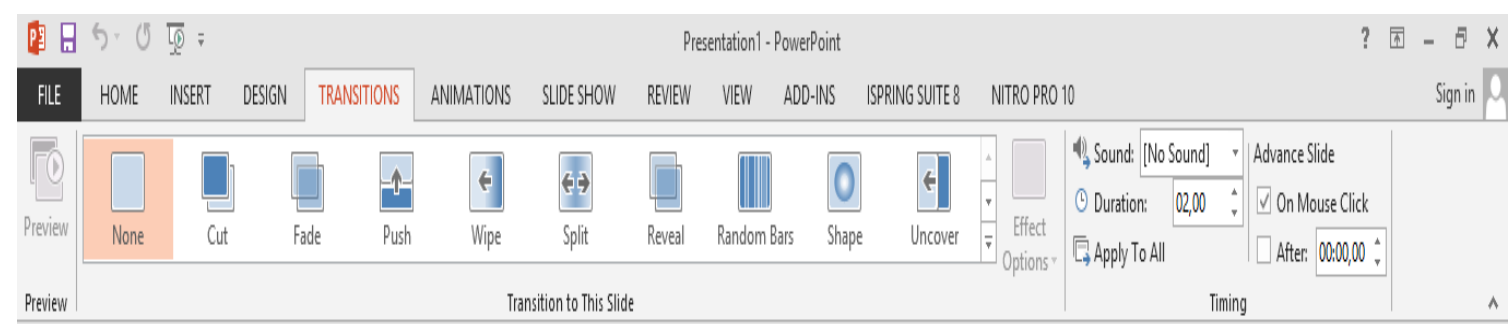

Gambar 4. Tampilan menu transitions microsoft powerpoint

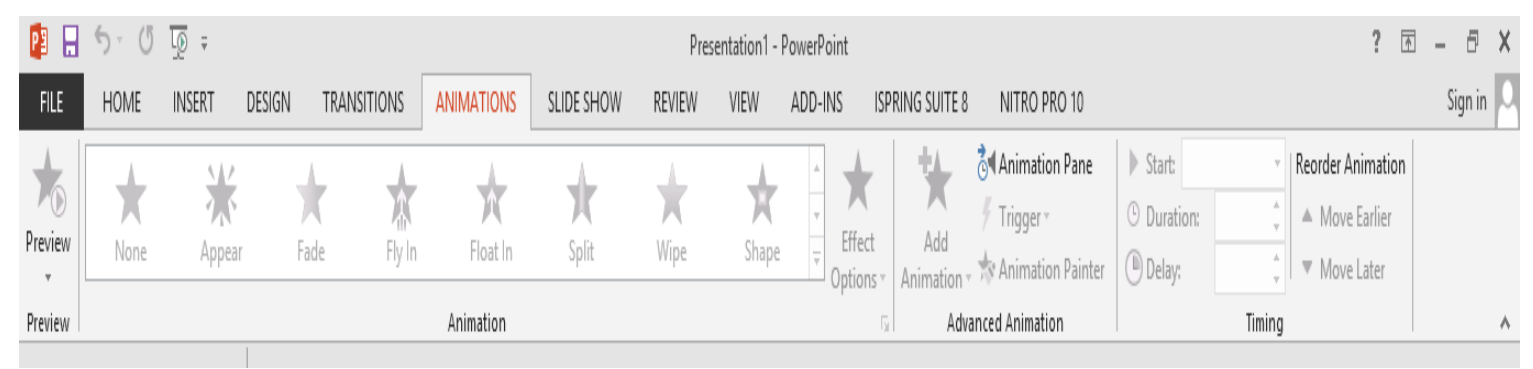

Gambar 5. Tampilan menu animations microsoft powerpoint

Selain kemudahan dalam satu folder dengan file presentasi penggunaannya terdapat juga kelemahan pada Powerpoint yang dibuat agar media dapat aplikasi Microsoft Powerpoint, diantaranya berjalan maksimal, sedangkan apabila file file audio/video yang disisipkan kedalam audio/video persentasi berbeda folder media pembelajaran pada Microsoft penyimpanan akan mengalami kendala yang Powerpoint harus disimpan menjadi membuat audio/video tidak berjalan atau 
tidak dapat dimainkan sehingga harus dilakukan pengaturan ulang.

\section{B. I-Spring Presenter}

Menurut Hernawati (2010:1) I-Spring Presenter merupakan salah satu tool yang mengubah file presentasi menjadi bentuk flash dan bentuk SCORM / AICC, yaitu bentuk yang biasa digunakan dalam pembelajaran dengan e-learning LMS (Learning management System). Perangkat lunak Ispring tersedia dalam versi free (gratis) dan berbayar. I-spring Presenter sendiri secara mudah dapat diintegrasikan dengan microsoft power point sehingga dalam penggunaannya tidak membutuhkan keahlian yang rumit. Ispring Presenter bekerja sebagai add-ins Power Point, untuk menjadikan file Powerpoint lebih menarik dan interaktif berbasis Flash. Media flash yang dihasilkan dapat dibuka di hampir setiap komputer atau platform. ISpring presenter juga dikembangkan untuk mendukung e-learning. Berbagai bentuk media dapat disisipkan ke dalam persentasi menggunakan I-Spring Presenter, sehingga media pembelajaran microsoft powerpoint terintegrasi dengan I-Spring presenter yang dihasilkan akan menjadi lebih menarik. ISpring presenter juga dapat merekam dan mesinkronisasi video presenter, menambahkan Flash dan video YouTube, mengimpor atau merekam audio, menambahkan informasi pembuat presentasi, membuat navigasi dan desain yang unik. Media pembelajaran yang dibuat dapat dengan mudah didistribusikan dalam format flash, yang dapat digunakan dimanapun dan dioptimalkan untuk web. $I$ Spring presenter juga dapat digunakan untuk mendesain kuis dengan berbagai jenis pertanyaan/latihan/soal dengan format seperti : True/False, Multiple Choice, Multiple response, Type In, Matching, Sequence, numeric, Fill in the Blank, Multiple Choice Text. Berikut beberapa gambar tampilan dari I-Spring Presenter

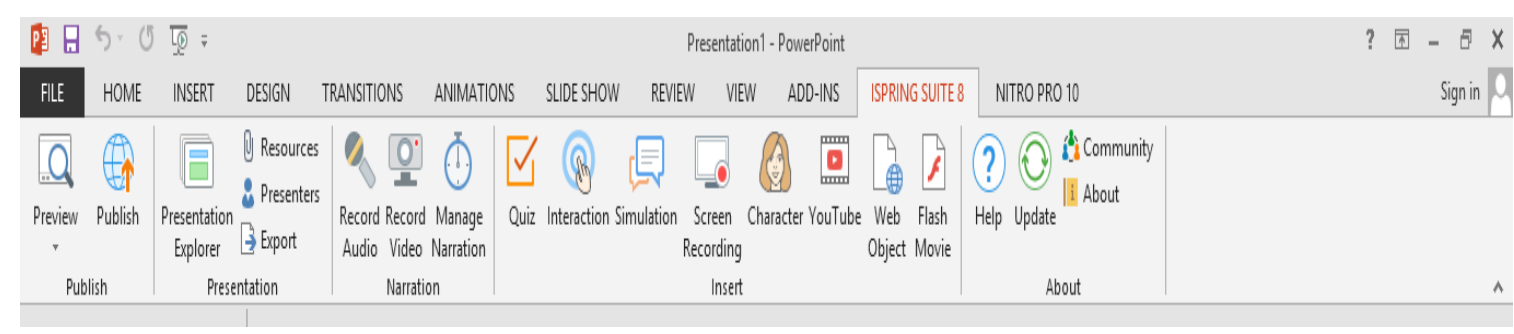

Gambar 6. Tampilan menu I-Spring Presenter 


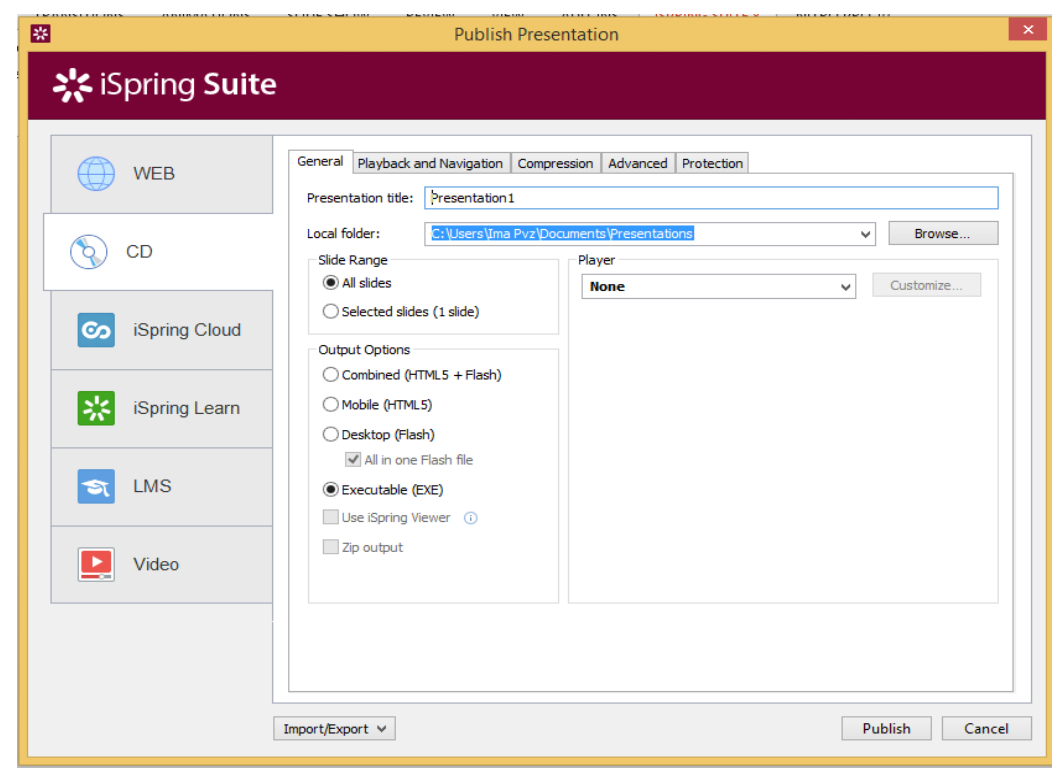

Gambar 7. Tampilan Publish Presentation I-Spring

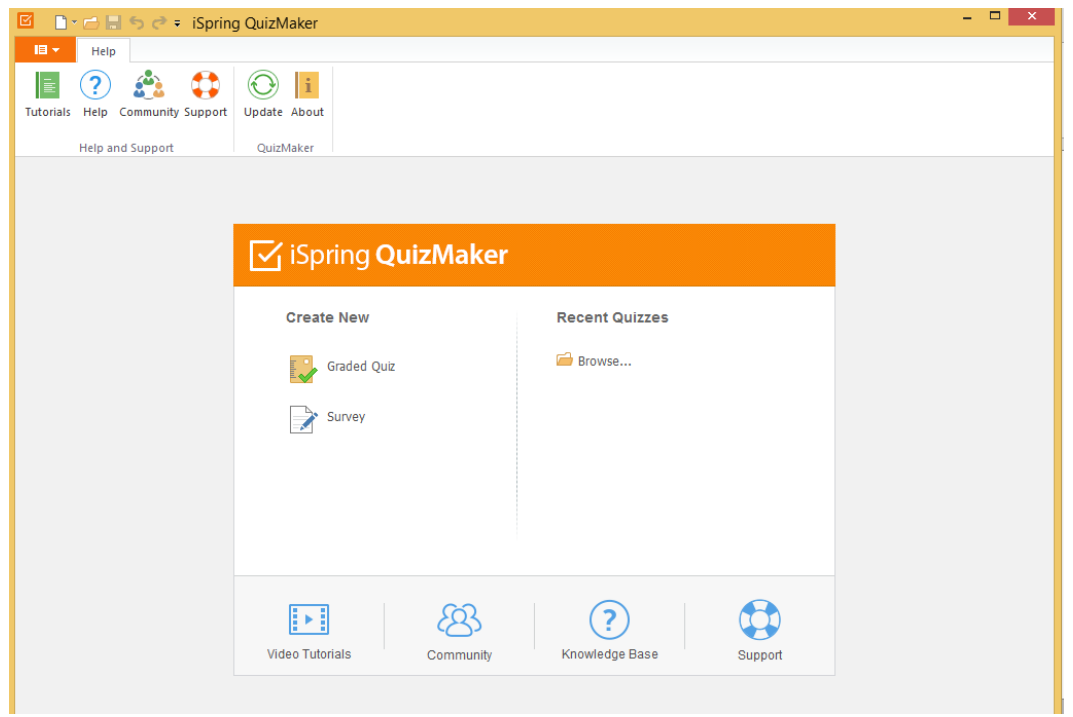

Gambar 8. Tampilan I-Spring Quismaker

C. Pemanfaatan Microsoft Powerpoint terintegrasi dengan I-Spring Presenter sebagai media pembelajaran ICT

Pembelajaran ICT merupakan salah satu matakuliah yang terdapat pada pada kurikulum perguruan tinggi STKIP Muhammadiyah Kotabumi. ICT merupakan salah satu matakuliah praktik yang memerlukan penguasaan yang baik sehingga dalam pengajarannya diperlukan suatu media pembelajaran yang tepat sebagai perantara penyampaian materi di kelas. Pemanfaatan microsoft powerpoint terintegrasi I-spring presenter dimaksudkan untuk memaksimalkan hasil desain media pembelajaran yang sebelumnya dibuat 
menggunakan aplikasi microsoft powerpoint lengkap dengan muatan gambar, animasi, audio dan video didalamnya untuk selanjutnya file persentasi akan dirubah dalam bentuk tampilan flash menggunakan aplikasi $I$ Spring Presenter. Kedua aplikasi ini sangat cocok dalam pembuatan media pembelajaran berbentuk persentasi. Untuk dapat menggunakan kedua aplikasi tersebut setidaknya pendidik harus memiliki kemampuan yang baik tentang teknologi dan komputerisasi. Powerpoint sendiri dapat digunakan untuk mendesain media pembelajaran yang menarik dan I-Spring presenter akan menjadikan media persentasi yang dibuat menjadi lebih menarik lagi. Media pembelajaran yang dibuat menggunakan microsoft powerpoint yang terintegrasi dengan $i$-spring presenter dapat membantu peserta didik untuk lebih termotivasi dalam memahami konsep pembelajaran yang disampaikan oleh pendidik. Sebagaimana beberapa hasil penelitian yang menunjukkan efektifitas dari media pembelajaran yang dibuat menggunakan Microsoft Powerpoint yang terintegrasi dengan I-Spring Presenter, diantaranya: 1) penelitian yang dilakukan oleh Wijayanto, et al. (2017), mengatakan bahwa multimedia interaktif yang digunakan sebagai metode pembelajaran dengan software Ispring dapat dijadikan sebagai sarana pembelajaran dalam meningkatkan motivasi dan kreativitas peserta didik. Media yang digunakan menjadikan peserta didik menjadi aktif dalam proses pembelajaran. Selain itu media juga dapat dijadikan sebagai bahan pembanding dalam mengembangkan media pembelajaran yang lebih baik. Media yang digunakan mampu meningkatkan minat dan motivasi peserta didik; 2)Penelitian lain yang dilakukan oleh, Yuniasih dkk (2018), dengan judul pengembangan media interaktif berbasis I-Spring materi sistem pencernaan manusia kelas $\mathrm{V}$ di SDN Ciptomulyo 3 Kota Malang, mengatakan bahwa media interaktif berbasis I-Spring layak atau sangat baik untuk digunakan sebagai media pembelajaran. Hal ini disimpulkan berdasarkan penilaian oleh ahli media mendapatkan presentase $85 \%$. Ahli materi mendapatkan presentase 94\%. Penilaian oleh calon pengguna dengan presentase $93 \%$. Penilaian hasil respon siswa pada saat ujicoba lapangan terbatas mendapatkan presentase $93 \%$.

\section{Kesimpulan}

Pemanfaatan microsoft powerpoint terintegrasi i-pring presenter dapat dijadikan sebagai alternatif dalam pembuatan media pembelajaran ICT. Media yang dihasilkan terintegrasi secara baik melalui tampilan audio visual yang menjadikan proses belajar mengajar menjadi lebih menarik, materi yang disampaikan lebih dapat difahami sehingga dapat memotivasi peserta didik, hal ini juga berdampak pada meningkatkan hasil belajar. 


\section{Daftar Pustaka}

Arsyad, Azhar. 2011. Media Pembelajaran. Jakarta: PT Raja Grafindo Persada

Asyar, Rayandra. 2012. Kreatif Mengembangkan Media Pembelajaran. Jakarta: Gaung Persada Press.

Fathurrohman, dkk. 2014. Strategi Belajar Mengajar. Bandung: PT Refika Aditama

Hernawati, Kuswati. 2010. Modul Pelatihan Ispring Presenter. Modul (online), (http:/stafnew.uny.ac.id/uploud/132309677/pengabdian/modul-ispring-presenter.pdf)

Rusman, dkk. 2012. Pembelajaran Berbasis Teknologi Informasi dan Komunikasi. Jakarta: PT RajaGrafindo Persada

Widada, H. 2010. Cara Mudah Desain Presentasi dengan Power Point 2007. Yogyakarta : Cakrawala.

Wijayanto P. A., Utaya S. \& Astina I, K. 2017. Increasing Student's Motivation and Geography Learning Outcome Using Active Debate Methode Assisted by Ispring Suite. International Journal of Social Sciences and Management, (Online), Vol. 4, No. 4 ( https://www.nepjol.info/index.php/IJSSM/article/view/18336, Diakses 15 Februri 2019)

Yuniasih, N., Aini, R. N., \& Widowati, R. 2018. Pengembangan Media Interaktif Berbasis ISpring Materi Sistem Pencernaan Manusia Kelas V di SDN Ciptomulyo 3 Kota Malang. JIP, Vol.8, No. 2 (http://ejournal.unikama.ac.id/index.php/jrnspirasi/article/view/2647, Diakses 12 Maret 2019) 